\title{
Memories of John Virgo
}

\author{
Joseph Daniels
}

Published online: 30 July 2013

(C) International Atlantic Economic Society 2013

\section{Keywords John Virgo $\cdot$ Society IAES}

When I was a young assistant professor, I had it in my head that I had to attend the Allied Social Science Associations meetings every year. This was in spite of the fact that I found the meetings to be too large and impersonal to meet colleagues and maintain relationships. I mentioned this to a friend, and he suggested that I try the International Atlantic Economic Society (IAES) meetings. I am glad he did, as the Society meetings emphasize collegiality. I am also glad that I had the opportunity to meet and develop a friendship with John and Kathy Virgo.

Thinking back on the years I have spent in the Society and the times I enjoyed with John and Kathy invokes many fond memories. Nonetheless, there was one event that stands above the others. In 2001, I was invited to Berlin by a delightful gentleman and economic historian, Wolfram Hoppenstedt. Wolfram was the director of the new Willy Brandt archives, located in the historic former city hall of West Berlin. The archives were certainly fascinating but being allowed into the room and balcony from which President Kennedy made his famous Berlin speech was the highlight of my visit. Wolfram proved to be a gregarious host with a wealth of information on the history of the city and quite an appetite for discussing American politics.

A few years later, in 2005, I was elected to the IAES Executive Board, and I delighted to hear that the spring 2006 meetings would be held in Berlin. New to the board, I wanted to make a contribution, and so I called up my old friend Wolfram. I asked Wolfram if we could make a visit to the archives as part of the events for the Berlin meetings. The answer, of course, was yes. I had witnessed all of the hard work that John and Kathy put into organizing the meetings, sessions, and social events, and being new to the Board, was a bit hesitant to approach John and potentially complicate matters. To my surprise, John told us to run with it. As I worked with Wolfram, one thing quickly led to another. A visit to the archives became a bus tour of the city, a reception at the archives, a tour of the building, a speaker, and so on. Wolfram was able to secure some funding and my department at Marquette University sponsored portions of the event. All the while I 
was checking with John, who not only gave us the freedom to plan the event but also encouraged us and expressed his gratitude.

By early 2006, the plans had gelled. I was very excited to attend the meeting and enjoy the program Wolfram and I had put together. Unfortunately, I was diagnosed with late-stage lymphoma. Not only could I not make the trip to Berlin, but I also had to withdraw from the Executive Board. In my calls and messages to John, he would not talk about the conference and was only concerned with my health. His kindness and concern was very touching. One of my colleagues, Farrokh Nourzad, went in my place, and John asked him to give a short speech on my behalf. From what I have been told, the conference was a smashing success. John continued to check in on me, and shortly after the conference, a card and a plaque arrived at my office, thanking me for my short time on the Executive Board.

After 2006, I had the chance to serve on the Board again and fulfill a full term. I have invited many young colleagues to the meetings, often organizing a dinner and inviting John to join us. I watched John patiently and calmly guide the Society through more than one financial crisis.

Over the years, especially in 2006, I learned three things about John. The first is that John treated everyone exactly the same. I have seen John talk with a Nobel Laureate one minute and an assistant professor who was attending the meetings for the first time the next. He treated both with the same level of respect and was equally enthusiastic to have both at the Society meetings. It reminds me of the respect he showed by placing confidence in me, and a German historian he had not yet met, to plan part of the meetings for the Society that he had committed so much of his time and attention.

The second is that John was one of the kindest and gentlest men I have ever met. The compassion and concern he showed me when I was struggling was heartwarming. He did not hide his tender side; I remember the sadness we shared when we lost our old friend Clarence Morrison.

On a lighter note, and in closing, the third thing I remember about John is that he had a plaque for everything. Whether you were a resigning Board member, a keynote speaker, the winner of a paper competition, or an undergraduate student paper competition finalist, John had a plaque. He never forgot to have a plaque, a hand shake, and a photo taken. That was his way of saying thanks for being a part of the Society, his Society, which he wanted to share with everyone. John will be missed. I hope all of us who remember John will continue to warmly welcome young economists to the Society and to treat our colleagues with compassion and kindness. And yes, don't forget a plaque when someone contributes.

With heartfelt memories,

Joe Daniels 